\title{
Protectors Become Perpetrators: An overview
}

\author{
Kalim Ullah \\ Lecturer, Department of Law, International Islamic University Chittagong
}

\begin{abstract}
The law enforcing agencies which are considered the key component of a democratic society all over the world are primarily responsible for the preservation of peace and order, protection of life and property of the citizens and prevention as well as detection of crime. But during the few years human rights violations by the law enforcing agencies in Bangladesh have increased alarmingly. In this paper an attempt has been made to focus the human rights violations that are alleged to have been done by the law enforcing agency and to explore the reasons why the protectors become perpetrators, to highlight the pattern of violations made by the law enforcing agency, their implications upon the law and order situation of Bangladesh. This paper also includes a critical appraisal of the existing laws governing the law enforcing agency and finally points out some recommendations for eradication of the loopholes haunting in our security forces and to make them as a force functioning by the law, under the law and for the law.
\end{abstract}

Keywords: Law enforcing agency, Human rights, Violation, Extra-judicial killing.

\section{INTRODUCTION}

In nutshell Law Enforcing Agency (LEA) is considered one kind of guardian to ensure 'Right to Fair Trial' in order to protect individual from the unlawful and arbitrary curtailment or deprivation of other basic rights and freedoms, the most prominent of which are the right to life and liberty of the person. The major attributes of fair criminal trial are enshrined in Article 10 and 11 of the Universal Declaration of Human Rights (UDHR) and Article 14 of the International Covenant on Civil and Political Rights, 1966 (ICCPR). The Constitution of Bangladesh also guarantees the right to fair trial through the Article 27, 31, 33 and Article 35. Also, the fundamental object of criminal law and criminal justice system is to control crime, punish the offenders, prevent crimes, protect innocents, and to maintain a fair degree of cohesion and stability in society. ${ }^{1}$ Being a law enforcement agency, Bangladesh Police plays a vital role in ensuring proper functioning of our Criminal Justice System so that the human rights of the people properly be ensured. The foundation of the criminal justice system is the Police reports regarding the criminal cases. Police reports are the primary sources and police do the preliminary works of a criminal case, based on which the judgments are delivered from the court. As the police are the framer, investigator and reporter of the case, there is huge scope for manipulation. ${ }^{2}$

Despite the different kinds of limitations, Bangladesh Police started "Police Reform Program (PRP)" in 2005 with the help of MoHA ${ }^{3}$, UNDP, DFID and the European Commission. One of the objectives of the PRP is to improve the efficiency and effectiveness of the Bangladesh Police by supporting key areas of access to justice including investigations, police operations and prosecutions; human resource management and training; strategic capacity and oversight; and most importantly the Criminal Justice System.

The first phase of PRP came to end in September, 2010. Within this time, there have many changes and developments been done regarding the training, policy making, infrastructure, methodology etc. of Police under the PRP. To some extent, Police also proposed some laws to the government in order to make Bangladesh Police more people oriented. ${ }^{4}$ Based on some successes and its importance, the second phase of the PRP has been launched in October, 2010 which is scheduled to be implemented within the year 2014 .

But, still the Human Rights Violations are common in our Criminal Justice System for which the law enforcement agencies are often being accused of. For an example, the Transparency International Bangladesh found that 75.6 percent of rural households and 58 percent of urban ones were forced to pay bribes to the police in order to receive services. ${ }^{5}$ Thus, corruption of Police is seriously affecting the criminal justice system. ${ }^{6}$ Not only corruption but also engaging themselves to violate the laws of the country even commits murder, missing, enforced disappearance etc. are common scenario in Bangladesh.

\subsection{Death in Custody:}

Custodial death becomes a common happening or incident in Bangladesh. The word 'custody' implies guardianship and protective care. No civilized law postulates custodial cruelty-an inhuman trait that springs out of a perverse desire to cause suffering when there is no possibility of any retaliation. ${ }^{7}$ In Jatiyo Mahila Ainjibi Samity vs. Bangladesh and Others, ${ }^{8}$ the High Court Division held that detention in safe custody against the 
will of a detained person was illegal. Basic Standard 8 states that 'All detainees must be treated humanely'. Protection of a detainee is a basic precept of police law as it is universally recognized. Right to human treatment as a detainee is recognized under many international instruments like:

a) Universal Declaration on Human Rights (art. 5).

b) International Covenant on Civil \& Political Rights (1966) (art .10)

c) Convention against Torture and Other Cruel, Inhuman, or Degrading Treatment or Punishment (1984).

The provision for the human and dignified treatment of prisoners and detainees serves as the basis for the positive obligations of state parties stated in Article 10(2) and 10(3) of the ICCPR, which are tailored to the criminal justice context. ${ }^{10}$ The Human Rights Council (HRC) stressed in general comment ${ }^{11}$ that, the following UN standards should be taken into account in interpreting and applying Article 10 of ICCPR, namely:

1. Standard Minimum Rules for the Treatment of Prisoners, adopted August 30, 1955;

2. Body of Principles for the Protection of All Persons under any form of Detention or Imprisonment. ${ }^{12}$

3. Code of Conduct for Law Enforcement Officials. ${ }^{13}$

4. UN Standard Minimum Rules for the Administration of Juvenile Justice (Beijing Rules). ${ }^{14}$

But whatever the laws both in national and international sphere, these legal mandates are absent in practice and that is why death in police custody is a growing phenomenon in Bangladesh. As to the Code of Criminal Procedure, custody of an accused means custody of the court in its ultimate sense. The transitional custody of a person may be with the police. But the ultimate authority to decide the fate of the suspect rests with the court. ${ }^{15}$ According to Odhikar documentation, a total of 104 and 76 people died in 2002 and 2003 respectively in the prison and police custody. ${ }^{16}$ In the year 2005, 1st October, Odhikar has published in the daily Prothom Alo that, number of death in custody and prison is 62.Odhikar's annual report of 2010 on human rights situation in Bangladesh said 109 people died in law enforcing agency's custody, 16 remain missing while they were held by the law enforcing agencies last year. The numbers were 123 and 02 respectively in 2009. In 2011, January to December the number were reported to 140.

Human rights group Ain o Salish Kendra has counted reported deaths of at least 150 people in socalled crossfires or gunfights and other means at the hands of different law enforcement agencies in the last nine months.

Of those killed extra judicially, the highest 83 people died in police custody, followed by 34 in elite force Rapid Action Battalion custody before and after their arrest. Other forces accused of extrajudicial killings are DB police (12 deaths), SWAT (12 deaths), joint forces (six deaths), BGB-police (two deaths) and Ansar/Rail police (one death). ${ }^{17}$

Following table shows the scenario of human rights violation in the last nine months.

Human Rights Situation (Jan-Sept 2016) ${ }^{18}$

\begin{tabular}{|l|l|}
\hline Number of persons killed & 83 \\
\hline Killed in Police custody & 34 \\
\hline Killed in RAB custody & 146 \\
\hline Killed in polls violence & 27 \\
\hline Killed by BSF along border & 96 \\
\hline Killed for dowry & 512 \\
\hline Incidents of rape/gang-rape & 11 \\
\hline Killed for protesting sexual assault &
\end{tabular}

\subsection{Torture}

Allegations of acts of harassment, attacks, torture and killings, perpetrated by the police and other law enforcement agencies are becoming more and more common. Members of law enforcement agencies are enjoying impunity due to the government practice of using such agencies against its political opponents, critics and dissenters. As a result, they have come to believe that they are above the law.

The International Standards of Police Behavior, and Code of Conduct for Law Enforcement Officials ${ }^{19}$, Art- 5 provides that, "No law enforcement official may inflict, instigate, or to tolerate any act of torture or other cruel, inhuman or degrading treatment or punishment, nor may any law enforcement official invoke superior orders or exceptional circumstances such as a state of war or a threat of war, a threat to national security, internal political instability or any other public emergency a justification of torture or other cruel, inhuman or degrading treatment or punishment."

Article: 1 of the Convention Against Torture and other Cruel, Inhuman or Degrading Punishment 1984 states that, "Torture means any act by which severe pain or suffering whether physical or mental, is intentionally inflicted on a person for such purposes as obtaining from him or a third person information, or a confession, punishing him for on act or a third person has committed, or is suspected of having committed, or intimidating 
or coercing him, or a third person, or for any reason based on discrimination of any kind, when such pain or suffering is inflicted by or at the instigation of or with the consent or acquiescence of a public official or other person acting in an official capacity."

Though Bangladesh is a signatory of the aforesaid Conventions, under the prevailing criminal law such kind of definition of torture has not been given and a Torture Bill is only lying before the table of Parliament. After a prolonged campaign, on October 24, 2013 the Torture and Custodial Death (Prevention) Act, 2013 was passed in the Parliament. Despite this, there is no change in the actual situation. Many police officers believe that information or confessions cannot be extracted without physical threat or torture. That is why, although torture is prohibited under the law, but its practice is rampant particularly under the 'remand'. The form of torture includes beating on the soles of the feet, hanging, and suspension by the arms while they are tied behind the back, suspension upside down, beating, electric shocks, and psychological forms of torture including humiliation, threat and insult etc. It is to be mentionable that, Shamim Reza Rubel, a student of Independent University of Bangladesh was arrested under section 54 of the Code of Criminal Procedure (Cr.PC) on July 23, 1998 and he died at the Detective Branch of Police office the day after his arrest. Bangladesh Legal Aid and Services Trust (BLAST) challenged sections 54 and 167 of the Cr.PC and filed a writ petition to the honorable High Court Division regarding this incident. In 2003, the High Court Division declared that parts of sections 54 and 167 of the Cr.PC were contrary to some Articles of the Constitution. The High Court Division ordered the amendment of the existing rules of arresting someone and interrogating him in custody under section 54 of Cr.PC, within six months. The Appellate Division of the Supreme Court dismissed the prosecution's appeal against the judgment and afterwards on November 10, 2016 the Court gave a 19-point instruction guideline. ${ }^{20}$ On November 15, 2016, Abu Salem Mohammad Noman, Magistrate of Chittagong Metropolitan Court ordered to conduct an investigation, after receiving allegations of the torture of Mohammad Musa with electric shocks. Mohammad Musa was arrested in a case filed under the Prevention and Suppression of Human Trafficking Act, 2012 by Potenga Police on November 5, 2016. SI Mohammad Mazharul Haque produced Musa before the Court on November 8, 2016 and sought remand for seven days. The Court fixed November 15, for remand hearing and Musa appeared before the court on that day. Musa informed the Court that SI Mazharul Haque, ASI Nur Nabi and ASI Partha Roy of Potenga Police Station had tortured him by giving him electric shocks. Musa showed the marks on his throat and hands to the Court. The Court ordered the Assistant Commissioner of the Detective Branch of Chittagong Metropolitan Police, to conduct an investigation into the allegations against the three police officers and submit a report within seven days. At the same time, the Court ordered the Civil Surgeon of Chittagong District, to check the health of Musa and submit a report to the Court. ${ }^{21}$ There are numerous incidents of tortures committed by the law enforcement agency which cannot be described by words.

Very often it seems that torture is committed on a person on the orders of 'higher-ups' which allows police to act with impunity. The lack of disciplinary action against law enforcement personnel remains one of the main attributing factors of torture.

The High Court Division in Alhaj Yousuf Ali vs.The State ${ }^{22}$ asserted against the police torture and spoke of a duty on part of the police that, "Law enforcement officials should be instructed that rape of women in their custody constitutes an act of torture that will not be tolerated. Similarly, they should be instructed that any other forms of sexual abuse may constitute torture or cruel, inhuman or degrading treatment and that offender will be brought to justice." In D.K Basu vs.State of West Bengal ${ }^{23}$ the Court found custodial torture 'a naked violation of human dignity and rule that law does not permit the use of third degree methods or torture on an accused person since actions of the State must be right, just and fair. Torture for extracting any kind of confession would neither be right nor just nor fair.'

Following table shows the scenario of torture to death by the Law Enforcing Agency (LEA) from 2001 to 2016.

\begin{tabular}{|c|c|c|c|c|c|c|c|c|c|c|c|c|}
\hline \multicolumn{13}{|c|}{ Torture to death by LEA $2001-2016^{24}$} \\
\hline \multirow[t]{3}{*}{ Year } & \multirow{3}{*}{$\begin{array}{l}\text { RA } \\
\text { B }\end{array}$} & \multirow{3}{*}{$\begin{array}{l}\text { Poli } \\
\text { ce }\end{array}$} & \multirow{3}{*}{$\begin{array}{l}\text { RAB } \\
- \\
\text { Poli } \\
\text { ce } \\
\end{array}$} & \multirow{3}{*}{$\begin{array}{l}\text { Join } \\
\text { t } \\
\text { For } \\
\text { ce } \\
\end{array}$} & \multirow{3}{*}{$\begin{array}{l}\text { Arm } \\
\mathbf{y}\end{array}$} & \multirow{3}{*}{$\begin{array}{l}\text { BGB } \\
\text { (form } \\
\text { er }\end{array}$} & \multirow{3}{*}{\begin{tabular}{l|} 
Coas \\
t \\
Guar \\
d
\end{tabular}} & \multirow{3}{*}{$\begin{array}{l}\text { DB } \\
\text { Poli } \\
\text { ce }\end{array}$} & \multirow{3}{*}{$\begin{array}{l}\text { Jail } \\
\text { authoriti } \\
\text { es/ }\end{array}$} & \multirow{3}{*}{$\begin{array}{l}\text { Nav } \\
y\end{array}$} & \multirow{3}{*}{$\begin{array}{l}\begin{array}{l}\text { Drugs } \\
\text { and }\end{array} \\
\text { Narcoti } \\
\text { cs }\end{array}$} & \multirow{3}{*}{$\begin{array}{l}\text { Gran } \\
\text { d } \\
\text { Total }\end{array}$} \\
\hline & & & & & & & & & & & & \\
\hline & & & & & & & & & & & & \\
\hline & & & & & & BDR) & & & Police & & & \\
\hline $\begin{array}{l}2016 \\
\text { (Jan- } \\
\text { Marc } \\
\text { h) }\end{array}$ & $\mathbf{0}$ & 3 & & & & & & & & & & 3 \\
\hline 2015 & 2 & 5 & & & & & & & & & & 7 \\
\hline 2014 & 1 & 9 & & & 1 & & & & & & & 11 \\
\hline 2013 & 1 & 10 & & & & & & & & & & 11 \\
\hline 2012 & $\mathbf{0}$ & 5 & & & & 1 & & & 1 & & & 7 \\
\hline
\end{tabular}


Protectors Become Perpetrators: An overview

\begin{tabular}{|c|c|c|c|c|c|c|c|c|c|c|c|c|}
\hline 2011 & 1 & 14 & & & & & & & 2 & & & 17 \\
\hline 2010 & 2 & 20 & & & & & & & & & & 22 \\
\hline 2009 & 3 & 11 & & & & 5 & 1 & & 1 & & & 21 \\
\hline 2008 & 3 & 8 & & & & 1 & & & & & & 12 \\
\hline 2007 & 2 & 14 & & 3 & 5 & & & & 1 & 3 & 2 & 30 \\
\hline 2006 & 4 & 23 & & & & & & & & & & 27 \\
\hline 2005 & 4 & 20 & & & & & & 2 & & & & 26 \\
\hline 2004 & 11 & 28 & & 7 & & & & & & & & 46 \\
\hline 2003 & & 16 & & 1 & 1 & & & 2 & 4 & 1 & & 25 \\
\hline 2002 & & 14 & & & 33 & 1 & & & 2 & & & 50 \\
\hline 2001 & & 8 & & & & & & & & & & 8 \\
\hline Total & 34 & 205 & 0 & 11 & 40 & 8 & 1 & 4 & 11 & 4 & 2 & 320 \\
\hline
\end{tabular}

\section{Violence against Women by Law Enforcing Agency:}

As to the behavior with woman the Code of Conduct for police personnel in police stations states that:

'Female visitors will have to be behaved with highest courtesy and manner and decency will have to be maintained in words and behavior with them.'

As to the responsibilities of officer in charge, this Code states that, 'If any female comes to an officerin-charge with complaint or for any other reason, he will give her standing welcome and behave with her decently. He will show courtesy and modesty in his behavior and conversation.'

Basic standard 7 of the '10 Basic Human Rights Standards for Law Enforcement Officials' States: 'Female detainees should be entitled to medical examination by a female doctor. They should be provided with all necessary pre-natal and post-natal care and treatment. Restraints should only be used on pregnant women as a last resort and should never put the safety of women or fetus at risk. Women should never restrain during labor.'

Basic standard 8 states: 'Female guards should be present during the interrogation of female detainees and should be solely responsible for carrying out any body searches of female detainees. Whatever be the national or international laws as to the behaviors of law enforcement officials towards women, the attitude of the police and the prison guards to female prisoners in the prison or jail is often crude and brutal.'

There is a rule that, when a woman is arrested by a female police officer must be present in the police station or the cell of the local police station during her stay there at night. But in Bangladesh, the number of police women cannot meet the requirement of all police stations. Human Rights Organizations alleged that the police in the absence of such process abuse and molest arrested women. ${ }^{25}$

The prisoners are regulated by Bengal Jail Code 1937, which includes the Prisoners Act of 1894. The Bengal Jail Code was turned into Bangladesh Jail Code after the country's independence in 1971. No tangible change was made in this code, except the formulation of the Children Act, 1974. The Jail Code allows the under trial prisoners with permission of the appropriate authorities to keep in touch with their families, friends and lawyers through frequent visits, letters and interviews in jails. But the inmates are sometimes denied the visiting right and their families are turned away at the jail gate if they do not pay bribes. ${ }^{26}$ In prison, most of the women come from poor families and with rural backgrounds. They mostly comprise of married, unmarried, divorced, and estranged women involved in begging, odd jobs and prostitution. So they are vulnerable to harassment and sexual abuse.

According to Regulation 327 of the PRB:

a) The accommodation of each lack-up shall be based on the scale of 36 square feet per prisoner.

b) a notice in English and vernacular language shall be hung up outside the lock-up at every police station and

c) post showing the maximum number of male or female prisoners which the lock-up is authorized by the government of accommodate.

But this rules are absent in our country. In addition, the practice of male prisoners cooking and serving food to female prisoners is also open to abuse by the male prisoners. ${ }^{27}$ Since social and religious believes compel people, to conceal the incidents of sexual violence, there is very little record of such incidents, apart from media coverage. Rapes of woman in police custody have increased significantly in the recent years. The cases of Yasmin $^{28}$ and Seema, reported in daily Newspapers are examples of gross violations of human security in police custody. These women supposedly in the safe custody of a law enforcement agency were raped and killed in the process. $^{29}$

Since the offenders are supposed to up hold the law, their liabilities are not acknowledged and charges are generally not brought against them. 


\section{Enforced Disappearance:}

The enforced disappearance of persons has been practiced since the mid-20th century. Enforced disappearances constitute an extreme violation of human rights, infringing many fundamental rights. Furthermore, not only the person is affected who becomes the direct victim, but also affected his or her family, colleagues and friends as well as society as a whole.

Most of the disappeared persons are those who are critics of their government. ${ }^{30}$ It is said that enforced disappearances are replacing the extra judicial killings in Bangladesh. According to Odhikar, the total number of enforced disappearances was reportedly 30 in 2011, 18 in 2010 and only two in 2009. While some of the 43 people who disappeared from January 2010 till November 2011 had prior criminal records, others were mostly clean, working as small traders, students or political activists. Robert O Blake, Jr. the State Department Assistant Secretary while attending the hearing at the US Congress, said that the Rapid Action Battalions is allegedly involve with extrajudicial killings and disappearances in Bangladesh. ${ }^{31}$

Infect, this type of criminal act is yet to be penalizing as a separate offence in Bangladesh. The International Federation for Human Rights, Asian Federation against Involuntary Disappearance and its local member Odhikar has already urged the Bangladesh government to ratify the International Convention for the Protection of All Persons from Enforced Disappearances.

Following table shows the scenario of enforced disappearances by the Law Enforcing Agency (LEA) from 2009 to 2016 .

Enforced Disappearances (2009-2016) ${ }^{32}$ :

\begin{tabular}{|c|c|c|c|c|c|c|c|c|}
\hline \multirow[b]{2}{*}{ Year(s) } & \multirow{2}{*}{$\begin{array}{l}\text { No. of the } \\
\text { disappeared }\end{array}$} & \multirow{2}{*}{ RAB } & \multirow{2}{*}{ Police } & \multicolumn{3}{|c|}{ Allegedly disappeared by } & \multirow[b]{2}{*}{ Ansar- } & \multirow[b]{2}{*}{ Other } \\
\hline & & & & RAB-DB & DB & Industrial & & \\
\hline & & & & Police & Police & Police & Police & \\
\hline 2016 (Jan- & 14 & 5 & 0 & 0 & 8 & 0 & 0 & 1 \\
\hline March) & & & & & & & & \\
\hline 2015 & 64 & 21 & 7 & 24 & 3 & 0 & 1 & 8 \\
\hline 2014 & 39 & 25 & 2 & 8 & 3 & 0 & 1 & 0 \\
\hline 2013 & 53 & 23 & 1 & 17 & 0 & 0 & & 12 \\
\hline 2012 & 26 & 10 & 1 & 0 & 6 & 1 & & 6 \\
\hline 2011 & 31 & 14 & 2 & 0 & 11 & & 0 & 4 \\
\hline 2010 & 18 & 14 & 2 & 0 & 2 & 0 & 0 & 0 \\
\hline 2009 & 3 & 3 & & & & & & \\
\hline Total & 248 & 115 & 15 & 49 & 33 & 1 & 2 & 31 \\
\hline
\end{tabular}

III. EXTRA JUDICIAL KILLINGS BY LAW ENFORCEMENT AGENCIES:

Before discussing any matter regarding extra judicial killing we have to precisely understand the meaning of extra judicial killing. Though there is no legal definition of an extrajudicial killing, if a death is caused by a law enforcement official without following the legal rules or due judicial process, it can be considered as extrajudicial killing.

Extrajudicial killing is defined as a deliberated killing not authorized by a previous judgment pronounced by a regularly constituted court affording all the judicial guarantees which are recognized as indispensable by civilized peoples. ${ }^{33}$

So, extrajudicial killing is the killing of a person by governmental authorities without the sanction of any judicial proceeding or legal process. 'Crossfire', 'gunfight' or 'encounters' are very common kinds of extra judicial killing in Bangladesh. After the killings of people, the police and RAB authorities have informed the media that the victims died after engaging in crossfire but it is found that in no case of 'crossfire' or 'encounter' whatever no member of RAB or Police has ever been injured or killed, which gives the impression that 'gunfight' was unilateral and it was done by the armed personnel.

3.1 Extra-Judicial Killing and Violation of the Right to Life and Right to Protection of Law:

The Holly Quran declares human life as sacrosanct. Allah said-

"Do not take life which Allah made sacred, except just cause. If anyone slew a person unless it be a murder or for spreading mischief in the land, it would be as if he slew the whole people; And if anyone saved a life it would be as if he saved the life of whole people. ${ }^{34}$

Article 31 of the Constitution of Bangladesh states that, "To enjoy the protection of law, and to be treated in accordance with law, is the inalienable right of every citizen, wherever he may be, and of every other person for the time being within Bangladesh, and in particular no action detrimental to the life, liberty, body, reputation or property of any person shall be taken except in accordance with law."

Article 32 of the Constitutions of Bangladesh, provides that there shall not be any deprivation of life ${ }^{35}$ or 
personal liberty expect in accordance with Law. The American Constitution also prescribes prohibition on all deprivation of life, Laverty or property without due process of law. ${ }^{36}$ Article: 3 of Universal Declaration of Human Rights states, "Everyone has the right to life. ${ }^{37}$ The International Covenant on Civil and political rights states vividly the right to life. ${ }^{38}$

The concept of due process has two aspects-procedural and substantive. The procedural due process makes it necessary that one whom it is sought to deprive of any right or liberty must be given notice of proceedings against him, must be given opportunity to defend himself. ${ }^{39}$

The due process of law includes the following requirements:

a. The law must be administered fairy.

b. A person must be informed of the charges against him and must be given a fair hearing.

c. The person bringing the charges must not be allowed to judge the case.

d. Criminal laws must be clearly worded so that they give adequate warning of the action prohibited.

In the cases of "crossfire" and "encounters," however, we find that these legal provisions are being totally ignored. The existing legal framework does not allow encounter killing. Such a concept cannot co-exist with constitutionalism, rule of law and the principles of democracy. Here we see that, according to the Due Process of Law extrajudicial killing not only violates the Right to Life and Right to Protection of Law but also contradicts the criminal justice system of a country.

\subsection{Extrajudicial Killing and Violation of the Principle of Natural Justice:}

Audi Alteram Partem (No man shall be condemned unheard) is a basic principle of natural justice that means no one is to be condemned, punished, or deprived of his/her life or property in any judicial proceeding, unless he/she has given an opportunity of being heard. The principles of natural justice have been violated repeatedly by law-enforcement agencies of Bangladesh through so-called "cross-fires'. On paper, a cross- fire is "the firing of guns from two or more different directions at the same time and passing through the same area." In practice, it has taken the shape of extra-judicial killings of alleged grievous offenders by law-enforcement agencies in the country. It is used often by the government to remain in power while denying the opponents a chance to be heard or condemn the actions of the government. The tendency to embrace extra-judicial killings as a necessary evil has resulted in a steadily increasing mistrust of the legal and judicial system.

Extrajudicial killings by the law enforcing agencies continued till now. The table below shows that extrajudicial killings by law enforcing agency from 2001 to 2016.

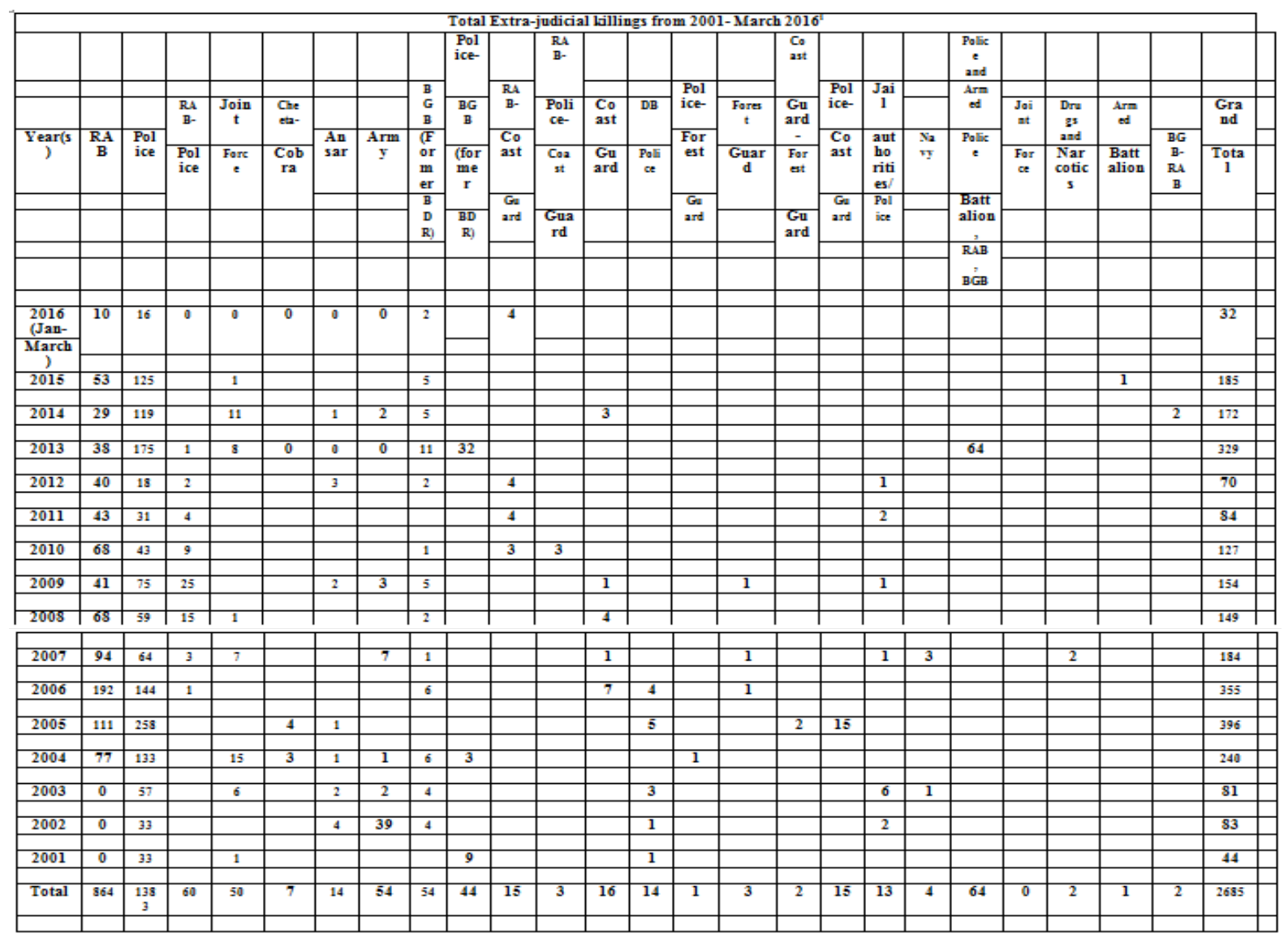




\section{POLICE AND CHILDREN}

Children are also victim of police's cruel behavior. In times of political unrest children are used for throwing explosive substance and stones. That is why police always have a tendency to arrest children under section 54 of the Cr.PC. In the Code of Conduct of Police as to the responsibilities with regard to the children, it is laid down that, 'Children will have to be behaved with soft words and in affectionate manners.'

As to the responsibilities of the officer-in-charge, the said Code cited that, 'in case of children or adolescents, officer-in-charge will behave with them with a vascular affection.' Many of the police stations in the country do not have separate custody room for children or female detainees. They are put in police cell with adults and common criminals, which is, in total contravention with the Jail Code and the Children's Act' 1974. Very often after arrest, what police doing is that they have not recorded the actual age of the children or mentioned extended age.

Under the ICCPR, children are generally considered to be individual' that enjoy full range of rights under the covenant. Article 10(3) requires the separation of 'juvenile offenders'. But all these provisions are not ensured properly in Bangladesh.

\section{CONCLUSION}

To protect the people from human rights violations in Bangladesh, the law enforcing agencies must be made accountable to people as well as to the court to uphold the reputation of our criminal justice system. Bangladesh still retained the Police Act 1861 which is tainted with colonial policing. Political and bureaucratic interference, low salaries, government's control of promotions and transfers etc. still remain as the major drawbacks of our security forces. Therefore, to bring the security forces in line with the 21 st century is a great challenge for us. The Police Reform Program (PRP) should keep all the above loopholes in mind before making any strategy in Bangladesh. The role of a vibrant civil society, NGO's, door agencies to create pressure upon the rulers of the Country to initiate strategic reforms cannot be overruled. Moreover, with institutional changes respect for human rights, rule of law and good governance should also be the safeguards for human rights in the domestic regime. If it is done, the security forces can be made accountable and friendly to the common people. Once the security forces are made accountable towards the people, the rate of human rights violations in Bangladesh will be decreased.

It is obvious that the PRP has many positive impacts on prevention of human rights violations in our criminal justice system. But there hindrances, loopholes, lacking exist that is limiting the impact and creating a bar to fulfill the goals of PRP. Considering the discussions, critical analysis, findings of the study, the following recommendations are given in order to make PRP more effective, to make the law enforcement agencies more people oriented and to prevent human rights violations in our country:

1. Incidents of extrajudicial killings by law enforcement agencies must be investigated and the perpetrators must be brought before the court of law.

2. The law enforcement agencies must follow the international guidelines "Basic principles on the use of Force and Fire arms by Law Enforcement Officials"

3. Effective measure should be taken by the Government to prevent the torture, death in the custody of the law enforcement agencies.

4. Feasible steps should be taken by the Government to turn the slogan or motto of the police 'Police is the friend of people' into the actual action.

5. The Government should abstain from applying force over the law enforcement agencies to control the oppositions.

6. The Government has to explain all incidents of enforced disappearance and post disappearance killings, allegedly perpetrated by the law enforcement agencies. The Government must bring the members of the law enforcement agencies who are involved disappearance or killings, to justice.

7. The Government should take all necessary steps to protect the rights of the citizens belonging to religious, ethnic and linguistic minority communities from transgression by the law enforcement agencies. Perpetrators of attacks on all minority communities and their places of residence, worship must be brought to justice.

\section{REFERENCES}

[1]. Faruque, Dr.Abdullah Al, Goals and Purpose of Criminal Justice System in Bangladesh: An evaluation, Bangladesh Journal of Law, Vol. 11, No. 1, (2011), p. 1.

[2]. European Commission, Activating the Justice System in Bangladesh, (2005)

[3]. Ministry of Home Affairs.

[4]. Dhaka, Jan 12, Bangladesh Sangbad Shanghtha (BSS) - Law Ministry is scrutinizing the draft of a proposed law entitled 'identification of the Convicted, Arrested, Suspected and Crime Scene Related 
Persons Act' Replacing Prisoners Identification Act-1920 to protect evidence of serious crimes.

[5]. Transparency International Bangladesh (TIB), Corruption in the Service Sectors: National Household Survey 2010,(December 2010), P-11.

[6]. Hasle, Lena, Too Poor for Rights? Access to Justice for Poor Women in Bangladesh: A Case Study, MSC Human Rights,,(2003/2004) P.7-8.

[7]. http://www.Lawyers jurists com/articles-and-assignment/custodial-death-is-a-gross-violations-of-humanrights

[8]. 59 DLR, 2007, 447,

[9]. Basic Human Rights Standards for Law Enforcement Officials prepared by Amnesty International, Page13,

[10]. Central European and Eurasian Law Initiative (CEELI), 740 15th ST., N.W. Washington, D.C. 20051022 P.8.

[11]. 11 Sir Shridath Sonny Ramphal QC served as Commonwealth Secretary General for 15 years, from 1975 to 1990 .

[12]. General Assembly. Res. 43/174, UN DOC A/43/49 (1988);

[13]. GA, Res. 34/169, (annex) UN, Doc A/34/46 (1979).

[14]. GA. Res. 40/33, Annex, 40 UN GAOR Supp. (No. 53) at 207, UN. DOC A/ 40/ 53.

[15]. Ibid

[16]. Project on Investigation, Research and Publication of Human Rights violations, Report 2003, Odhikar, page.105.

[17]. http://www.dhakatribune.com/bangladesh/law-rights/2016/09/30/ask-150-custodial-deaths-nine-months

[18]. Survey conducted by Ain o Salish Kendra (ASK) in 2016

[19]. General Assembly resolution 34/149

[20]. The daily Jugantor, 11/11/2016; http://www.jugantor.com/first-page/2016/11/11/75611.

[21]. The Daily Protom Alo, 15/11/2016;www.protom-alo.com

[22]. (2002) $22 \mathrm{BLD}(\mathrm{HCD}) 231$.

[23]. AIR 1997, SC, 610.

[24]. Survey conducted by Odikhar (Non-Governmental Organization).

[25]. The Daily Star, August 25, 2002

[26]. Ibid

[27]. Human Security in Prison: The Quest for Protection and Reforms of Prisoners, Human Security in Bangladesh, in Search of Justice and Dignity, UNDP, 2002. Page.85.

[28]. Arafat Ameen, Criminal Responsibility for Torture: An urgent Human Rights safeguard in Bangladesh; Criminal Responsibility for Torture, A South Asian Perspective, Research Report 2004,

[29]. Violence and Repression against Women and Children: An Unending Agenda, Human Security in Bangladesh, in search of Justice and Dignity, UNDP, 2002, Page. 103,104.

[30]. http://www.apdh-argentina.org.ar/relaciones_internacionales/2009/enforced-disappearence.

[31]. Bdnews24.com, 20July, 2012, at http://bdnews24.com/details.php?cid=2\&id=228562, last visited on 20 December, 2012

[32]. Survey conducted by Odikhar (Non-Governmental Organization).

[33]. Sinaltrainal v. Coca-Cola Co., 2009.

[34]. The Holy Al-Quran 17:33, 5:55

[35]. Life within the meaning of art-31 means something more than mere animal existence, Munn v People of Illinois, 94 us 113 (per field J) as cited in Mahmudul Islam, Constitutional Law of Bangladesh”, Mulick Brothers, Dhaka, 2012. p.167.

[36]. Fifth Amendment of the American Constitution, 1777.

[37]. Right to Life means "Right to necessary condition of life." Francis Coralie Vs. Union of Delhi, AIR 1 $981 \mathrm{SC}$

[38]. The International Covenant on Civil and political rights, 1966, Article 6.

[39]. Ibid 